\title{
Power, Conflicts, and Environmental Communication in the Struggles for Water Justice in Rural Chile: Insights from the Epistemologies of the South and the Anthropology of Power
}

\section{Cristian Alarcón Ferrari}

\begin{abstract}
INTRODUCTION
This chapter aims at advancing a conflict- and power-oriented conceptualization of environmental communication to analyze and explain struggles for water justice in Chile. In doing so, the chapter draws insights from the epistemologies of the South and the anthropology of power to more deeply understand environmental communication processes and to highlight the explanatory and analytical potential of a critical conceptualization
\end{abstract}

\footnotetext{
C. Alarcón Ferrari $(\bowtie)$

Department of Urban and Rural Development, Swedish University of Agricultural Sciences, Uppsala, Sweden e-mail: cristian-alarcon.ferrari@slu.se

(C) The Author(s) 2022

A. Sjölander-Lindqvist et al. (eds.), Anthropological Perspectives on Environmental Communication, Palgrave Studies in Anthropology of Sustainability, https://doi.org/10.1007/978-3-030-78040-1_9
} 
of environmental communication (see also Alarcón, 2015, 2019, 2020). The chapter builds and elaborates upon insights into power and communication developed by Paulo Freire and Eric Wolf to dialectically approach issues of hegemony, ideology, and discourses, and to more deeply address power relations and conflicts in the conceptualization of environmental communication. I argue that making sense of those dialectical interrelations serves to advance a critical conceptualization of environmental communication in both theoretical and empirical terms. Closely linked to a critical conceptualization of environmental communication, the chapter elaborates some normative perspectives for a situated understanding of environmental communication which builds upon Freire's engaged theoretical approach to communication, developed in the context of past political struggles in Chile. Empirically, the chapter focuses on the analysis and explanation of struggles for water justice and water democracy in Chile, providing empirical insights from fieldwork conducted in three administrative regions of Chile, including interviews, observations, and analysis of documents in Southern and Central Chile in recent years.

\section{Environmental Communication from a Conflict- and Power-Oriented Perspective}

To start with, I would like to stress that the relevance of a conflict- and power-oriented conceptualization of environmental communication arises from the fundamental place that this form of communication occupies in the current struggles around the present and the future of human interactions in ecosystems. Within this context, a sound theoretical approach to environmental communication has the potential to contribute to addressing in analytical and explanatory terms what Joas and Knöbl define as the three specific questions in the social sciences, namely: What is action? What is social order? And what determines social change? (Joas \& Knöbl, 2009). Furthermore, I maintain that a critical conceptualization of environmental communication can bring new theoretical and normative perspectives to critical theories trying to better understand the fundamental role of power in today's specific social-ecological conflictivity. Here it is important to consider that there has long been an ample recognition that despite its wide use, power is a "slippery and problematic concept" (Martin, 1971). In Steven Lukes's influential approach to power, following Gallie (1955), power is seen as an "essentially contested concept," one 
of those notions which "inevitably involve endless disputes about their proper uses on the part of their users." In addition, as Lukes argues, to engage in conceptual disputes on power is itself to engage in politics (Lukes, 2004). Recently, and when addressing power in social theory, it has been recognized that there is a fundamental relation between human communication and social power, and in one of the most ambitious recent attempts to see power from a communicative angle, Manuel Castells argues as follows: "Power is primarily exercised by the construction of meaning in the human mind through processes of communication enacted in global/local multimedia networks of mass communication, including mass self-communication" (2013, p. 416).

Since the use of communicative strategies has become a pervasive process identifiable in today's environmental conflicts, struggles, and fundamental sustainability challenges, Castells's overarching statement concerning communication in the exercise of power provides an important starting point for thinking more deeply about environmental communication. Widely and descriptively speaking, environmental communication research has often been conceived as a field of studies concerned with the role that intersubjective communication plays in connection with ecosystems and the use of ecological resources (Alarcón, 2015). As a field of study, environmental communication is characterized by a focus on interpreting conflicts and environmental crises associated with political processes linked to the use of resources and human interactions with ecosystems. An important claim in environmental communication research is that it explores the constitutive dimension of communication and aims at advancing nuanced explanations of relationships between the symbolic and the material (Schwarze, 2007). Within this context, a premise that is often shared in this field of study is that the social process of communicating about ecosystems implies different assumptions, values, and beliefs about ecosystems and possible uses of ecosystem resources. Thus, Milstein (2009) conceives environmental communication scholarship as the study of how people communicate about the natural world, ascribing to environmental communication scholars the belief "that such communication has far-reaching effects at a time of largely human-caused environmental crises" (Milstein, 2009, p. 344). In turn, Robert Cox's influential work in the field in the North American context focuses on public spheres to look at the articulation of different views and meanings concerning the environment which, in his view, are articulated through environmental communication. For Cox, environmental communication 
should be understood as the "pragmatic and constitutive vehicle for our understanding of the environment as well as our relationships to the natural world; the symbolic medium that we use in constructing environmental problems and in negotiating society's different responses to them" (Cox, 2010, p. 37).

Issues concerning public participation in environmental management are an area of especial concern for environmental communication research (Senecah, 2004), and this is also one of the areas where a body of literature has specifically taken an environmental communication perspective to address issues of power in environmental conflicts. Todd Norton (2007), for example, employs Giddens's structuration theory to highlight what he terms the dialectic of control, where, in his view, even in contexts of great disparities in power, rarely does one agent completely monopolize power. Thus, for Norton, all agents "have some degree of power or the capacity to influence," and in his view "agents utilize power at their disposal to change circumstances and processes consistent with their desired interests." This relational view of power still needs to be more deeply connected to the existence of different interests and how those interests intersect with the deployment of environmental communication by different actors. A way to address this has been to think about power relations along with contingent relations of authority and influence. Robert Cox (2010), for instance, examines strategic dimensions of climate change communication by stating that meanings are produced within networks where power is contingent upon certain sites and through which "lines of authority and influence flow." Yet, I would argue that to separate meaning and power may analytically obscure the understanding of how and why the very acts of producing different meanings are in fact themselves acts of power. In this regard, Deborah Cox's analysis of public participation models highlights the fact that power both enables and constrains participation (Cox Callister, 2013).

These examples, taken selectively from the environmental communication literature focusing on power and communication, show us that environmental communication gets deeply entangled in the many facets of contemporary power relations in social-ecological contexts. They also suggest that it is important to more deeply analyze what I term here processes of communicative struggles, which, I argue, requires a conceptualization of communication that can be theoretically articulated with other key communicative processes such as hegemony, ideology, and discourse. In elaborating on that, I would like to briefly recall the theoretical process 
through which Habermas proposed his still influential theory of communicative action. For this, we need to keep in mind that Habermas first theorized about what he identified as systematically distorted communication to more specifically understand how in capitalist and class societies communication is entangled in contexts where "irreconcilable interests are recognized as antagonistic interests" (1973, p. 27). Yet, as Hanno Hardt reminds us, when thinking about communication, it is important to consider the etymological roots of the term communication. Hardt further highlights that communication has been applied (as a noun) to a wide variety of practices that establish, above all, commonality (2008). Thus, in following this basic conceptual dimension in our understanding of communication, one can state that considering communication as the process of "making common" is key when outlining a critical approach to communication in environmental communication research. This also means that it is important to better explain why and how the distortion of the act of making common arises, which, as Habermas suggests, originates in the confrontation of different and incompatible subjects' claims and interests in class societies where the consciousness of that incompatibility makes conflicts manifest. Within this context, what Habermas once analyzed in terms of systematically distorted communication continues to be relevant when trying to normatively assert communication as the process of "making common" in relation to contemporary social-ecological conflicts where environmental communication plays a defining role. In this regard, the argument developed by Latin American political ecologist Enrique Leff in his book Ecology and Capital is illuminating. For Leff, the ideological formations "covering the environmental field produce discursive practices and their function is to make neutral in the conscious of subjects the conflicts originated in divergent interests" (Leff, 1994, p. 78, trans. Cristian Alarcón). These insights, I would argue, call for a deeper exploration of the relations between power and conflicts in environmental communication to shed light on the relations between ideology, discourse, and hegemony. I argue that this opens a conceptual terrain for a more critical conceptualization of environmental communication for which the anthropology of power and the epistemologies of the South offer important insights. Thus, I shall now provide such perspectives by focusing on the paths for theorizing power and communication outlined by Eric Wolf and Paulo Freire. 


\section{Anthropologies of Power, Epistemologies of the South, and Their Relevance for a Critical and Situated Conceptualization of Environmental Communication}

The task of theorizing power in social-ecological contexts characterized by conflicts and struggles for the access and use of resources links the previous discussion to ongoing conceptual discussions within anthropology (Franquesa, 2019). Within this context, authors rethinking the anthropology of power have put into question state-centric views on power since, as it is argued, state centrism obscures the multilevel processes that are inherent and contingent to power relations (Cheater, 1999).

In advancing a contemporary research agenda for the anthropology of power, Mexican anthropologist Jose Luis Escalona (2016) proposes a framework which includes the following four dimensions of a contemporary anthropology of power. First, an epistemological shift from a dualistic view of worldwide society toward a focus on ongoing, interconnected, and emigrant-oriented humankind. Second, recognition that power relationships also imply constant negotiation and struggle, that politics are a means of disputing and transforming society. Third, to continue reconsidering power, politics, and the state theoretically, and to understand power relations as differential capacities and strategies to make society, in a range of mutually constituting scales and contexts. Fourth, in addition to pure civil society, public spaces, and transparent political debates, we need to attend more deeply to realms colonized by other idioms/performances that include sorcery, witchcraft, gossip, rumor, ritual, and demagoguery (Escalona, 2016). I find it especially relevant to highlight here that when Escalona argues for a recognition of politics and power as a process of constant negotiations and struggles, and politics as a means of disputing and transforming society, he calls attention to "ways in which naming (one of the main instruments of social power) contributes to building and destroying institutions, by conceptualizing, pretending, silencing, resisting, and criticizing." Here, naming is interconnected to power in ways that imply considering power arenas of disputed domination and control, and thus imply "intentional lies and miscommunication" (Escalona, 2016). This insight is particularly relevant when analyzing the reality of political processes in environmental conflicts and everyday processes of political contestation in communicative terms. Within this context, two of 
Eric Wolf's insights addressing the relations between power and communication are of particular relevance. The first is Wolf's distinction between four modes of power (2001), which, drawing also from Irene PortisWinner (2006), I summarize as follows:

1. Power as an attribute of a person, his or her individual potency, or capability. For Wolf, this refers to the "endowment of persons in the play of power, but tells us little about the form and direction of that play" (Wolf, 2001, p. 384).

2. "Power as the ability of an ego to impose its will on an alter, in social action, in interpersonal relations. This draws attention to the sequences of interactions and transactions among people, but it does not address the nature of the arena in which the interactions transpire" (Wolf, 2001).

3. Tactical or organizational power means controls of the settings in which people may put forth their potentialities and interact with others. This takes Adams's definition of power not in interpersonal terms, "but as the control that one actor or 'operating unit' (his term) exercises over energy flows that constitute part of the environment of another actor" (Wolf, 2001; see also Adams, 1975).

4. Structural power is "power that not only operates within settings or domains but that also organizes and orchestrates the settings themselves, and that specifies the distribution and direction of energy flows" (Wolf, 2001). Here Wolf links this mode of power to what Marx identified as "the power of capital to harness and allocate labor power," and in Wolf's approach "forms the background of Michel Foucault's notion of power as the ability 'to structure the possible field of action of others" (2001). This term rephrases the older notion of "the social relations of production" and is intended to emphasize the power to deploy and allocate social labor. For Wolf, structural power "shapes the social field of action so as to render some kinds of behavior possible, while making others less possible or impossible" (2001).

I see Wolf's modes of power as a relational approach, one which cautions us not to conceive power as a mere capability. Especially important here is how Wolf connects structural power to the social field of action. In this regard, the second important set of theoretical insights in Wolf's anthropological theory that I want to highlight has to do with how Wolf 
conceives power in communicative processes within conflict-laden contexts. In this regard, Wolf challenges views on communication that are oblivious to the deep connections between power, communication, and conflicts, stating, "We do not attack reality only with tools and teeth; we also grasp it with the forceps of the mind-and we do so socially, in social interaction and cultural communication with our fellows and enemies" (Wolf, 2001, p. 315). Wolf goes further and theorizes the communicative nature of conflicts in relation to the process of signification, and in criticizing some versions of symbolic anthropology, he affirms that "although signification is intimately tied up with issues of social power, 'normal' linguistics and symbolic anthropology have operated with a model of equal and power-neutral communicators or culture bearers, homogeneous speakers of language A or carriers of culture B" (2001, p. 377). In the same context, Wolf stresses that "in communication signifiers and signifieds are soldered together and supposedly arbitrary connections are in fact socially anchored and motivated" (2001, p. 378). Crucially, Wolf emphasizes here that power is deeply ingrained in the everyday use of human language: "All speakers in a linguistic community may use language, but what some people say and make others say is more fraught with social power than are the words of others" $(2001$, p. 378). In this regard, Wolf adds that more power-laden messages or utterances should be called "ideology," and that it is a research task "to look for these power-laden chains of signification and to study their implication for the maintenance or dissolution of social relationships" (2001, pp. 378-379).

At this point, I would like to stress that Wolf's theorizing of connections between communication and power offers a productive way to engage the anthropology of power with a critical conceptualization of environmental communication. Especially relevant here is to discuss the tendency in environmental communication research to attribute normative dimensions to communication on the environment without recognizing that conflicts and power are not an externality to different communicative practices on the environment, but are rather a constitutive aspect of such communication. In fact, if power relations are so ingrained in the communicative production and reproduction of current capitalist societies as Wolf and other have maintained, we need to first explain the role of communication in conflicts, and only after that may we be able to properly analyze how different forms of environmental communication could contribute to fostering normative alternatives to those conflicts. 
These anthropological insights on power and communication help to advance a power- and conflict-oriented perspective on environmental communication. They also bring into this discussion the task of defining specific ways and contexts for environmental communication where power, knowledge, and environmental communication get entangled through conflicts. Thus, in what follows, I will continue advancing a critical conceptualization of environmental communication by bringing insights from the epistemologies of the South and the work of Paulo Freire.

I will start by observing that there is a fundamental anthropological approach in Freire's work, and this concerns precisely power and communication. As McKenna asserts,

Freire was, in fact, an anthropological educator. He founded an educational movement based, in part, on conducting an ethnographic evaluation of a community to identify the generative themes (or 'dangerous words') which matter profoundly to people and which, for just this reason, contain their own catalytic power. (McKenna, 2013)

Bearing that in mind, I will elaborate on Freire's contemporary relevance to the theorizing of communicative struggles and to the understanding of environmental communication thereby. For this, I will focus specifically on Freire's essay "Extension or Communication" (1973) and also draw insights from his Pedagogy of the Oppressed (2000) to build on Freire's theorizing on communication as follows. First, Freire's works offer both a critique of existing communication and normative views on communication which are centered on conflicts and power relations in the context of struggles for resources and meaning. Second, Freire's conceptual reconstruction of the communicative dynamics in social struggles in South America opens a productive way to more deeply explore communicative struggles in terms of struggles over the very process of knowledge production. This is exemplarily shown in his critique of agricultural extension and his arguments for intercommunication in the context of his pedagogical work among peasants and extensionists during the struggles for the Agrarian Reform in 1960s Chile (Freire, 1973). Here, Freire approached micro-level processes of communication as processes of intersubjectivity in the wider context of political struggles, and he linked this to ideological and class relations of power. Third, Freire provides a dialectical understanding of communication which allows us to distinguish in clearer terms issues concerning for whom and for what communication serves, and it 
also provides context-specificity to communication, intercommunication, and intersubjectivity as a primary focus of attention. Fourth, Freire's analysis of social struggles develops a unique combined critique of existing communication along with the search for utopian possibilities arising from the intersubjective process of formation of sociality through communication.

Taking the previous insights together, I would argue that Freire's theorizing of communication calls attention to what I understand as spaces of communicative struggle. Here, Freire's work is lent continued relevance by a contemporary world deeply defined by social-ecological crises and struggles; ours can be seen as a time of specific communicative struggles where the materiality of expanding social-ecological crises moves along with subjective and intersubjective meaning-making within such communicative struggles. Conceptually, this means that it is not possible to simply conceive environmental communication as a neutral process. Thus, thinking about environmental communication from that perspective implies recognizing that environmental communication is produced through confrontation between different views of society and ecology, and this expresses conflictivity and struggles between mutually antagonistic sectors and classes in society. In such contexts, it is not possible to conceive environmental communication as a conflict-free process or a process that can neutrally intervene in struggles without becoming part of such struggles. Thus, bearing in mind this broad contemporary problematic in a global time and space of communicative struggles of a social-ecological nature, Freire's unique insights from situated communicative struggles offer conceptual paths to better address issues of power, conflicts, and communication concerning the following conceptual problems.

First, we can observe that, in today's environmental conflicts, the interests of mutually divergent and antagonistic sectors of society are expressed in terms of environmental communication. Thus any understanding of environmental communication in such contexts should be oriented toward theoretically explaining actors and interests in ways that fully consider conflictive social-ecological relations where environmental communication is part of antagonistic and ideological views on what societies and ecological relations are and should be. Second, and in the more particular context of analyzing the social-ecological nature of struggles and conflicts, it is important to analyze how environmental communication and discourses have in fact become an articulating process shaping struggles and conflicts in contemporary societies. Here, ideological dimensions of 
communicative processes are inseparable from environmental communication because environmental communication is a basic link constituting ideological relations to the environment. One way to analytically approach such conflicts is to conceive of the existence of dialectical relations between ideology and environmental communication. In turn, the combination of environmental communication and ideological processes of knowledge production give basis to environmental discourses.

Third, it is important to consider how the analysis of the processes outlined earlier and their interaction in and within the materiality of socialecological relations may allow us to better understand hegemonic processes today. Here the production of hegemony is always the result of the articulation of communication, ideology, and discourses. In more particular terms, environmental communication articulates those three communicative processes, where hegemony should always be understood as a process and never as a static reality. In this regard, environmental communication in the context of communicative struggles for resources becomes a primary process in the production of knowledge.

The preceding elaboration, I argue, provides a conceptual background for an exploration of how a power- and conflict-oriented perspective on environmental communication helps to more deeply explore interdependencies between knowledge and power. This also entails fully considering the epistemological dimensions of conceptualizing environmental communication. The terms that capture this epistemological dimension of environmental communication are, to me, connected to what Boaventura de Sousa Santos and others have understood as epistemologies of the South (de Sousa Santos, 2012, 2015, 2018). In fact, as de Sousa Santos recognizes, one of the main sources of the epistemologies of the South is the work of Paulo Freire. For de Sousa Santos, a fundamental definitional moment of the epistemologies of the South is that these are not confined to institutional practices:

They combine institutional and extrainstitutional practices. They are political to the extent that they constitute ways of knowing and validating knowledge that aim to contribute to the refoundation of insurgent policies capable of efficiently confronting the current, insidious, and techno-savage articulations between capitalism, colonialism, and patriarchy. Such policies, just like the epistemologies grounding them, occur inside and outside of institutions, in parliaments, governments, and judicial systems, as well as, whether 
formally or informally, in streets, squares, communities, and social networks. (de Sousa Santos, 2018, p. 248)

Thus, epistemologies of the South cannot be separated from the centrality of the struggles where institutional and extrainstitutional practices take the forms of "criticism and possibility, nonconformity and resistance, denunciation and counterproposal," which in de Sousa Santos's view can be "more or less consolidated, more or less formalized, and of longer or shorter duration" $(2018$, p. 248). In the context of discussing environmental issues, the central role of communicative struggles entails radical conceptual ruptures from hegemonic ways through which environmental issues are often framed and analyzed. That is the case of discourses on adaptation, resilience, sustainable development, and the like, which are oblivious to conflict-laden realities and struggles for resources. Bearing this in mind, I offer further an analysis of struggles for water justice in Chile through the lens of a power- and conflict-oriented critical conceptualization of environmental communication.

\section{Environmental Communication and Power in the Struggles for Water Justice in Chile}

An increasing number of water conflicts have surfaced in Chile during recent years in the context of a water crisis caused partly by a long drought which started in 2010 . Yet, the water crisis is not only a process pertaining to lack of rain. This is a water crisis that cannot be understood without considering a legal and constitutional framework for water management that ensures private property rights over water resources in an economic context of production for export that requires enormous quantities of water. In fact, privatization of water is deeply connected with the imposition of neoliberalism in Chile (Budds, 2013). Within this context, the first assessment of water scenarios for Chile in 2019 confirmed the existence of serious water stress in the whole country, with urban and rural areas already severely hit by water scarcity. In a 2019 interview, staff assessing the water scenarios explained that

[a]ll the [economic] sectors in the territories projected growth, and when you reviewed their long-term visions, you saw that the mining sector, the agricultural sector, the tourism sector, the sanitation sector, all of them projected growth, and you looked at the data and you said, 'Well, and with what 
are they going to grow if the water [availability] decreases?' (Interview, Staff at Escenarios Hídricos, October 2019, trans. Cristian Alarcón)

Recently, the urgency of thinking and implementing policies to address water scarcity due to climate change, overconsumption, and droughts, and the increasing political opposition to the neoliberal order in Chile has created new political conditions for questioning the privatization of water resources, and the demand for ending privatization of water figured prominently during the popular uprising in October 2019. The photos in Fig. 1, taken in December 2019 in Santiago, show spray-painted political
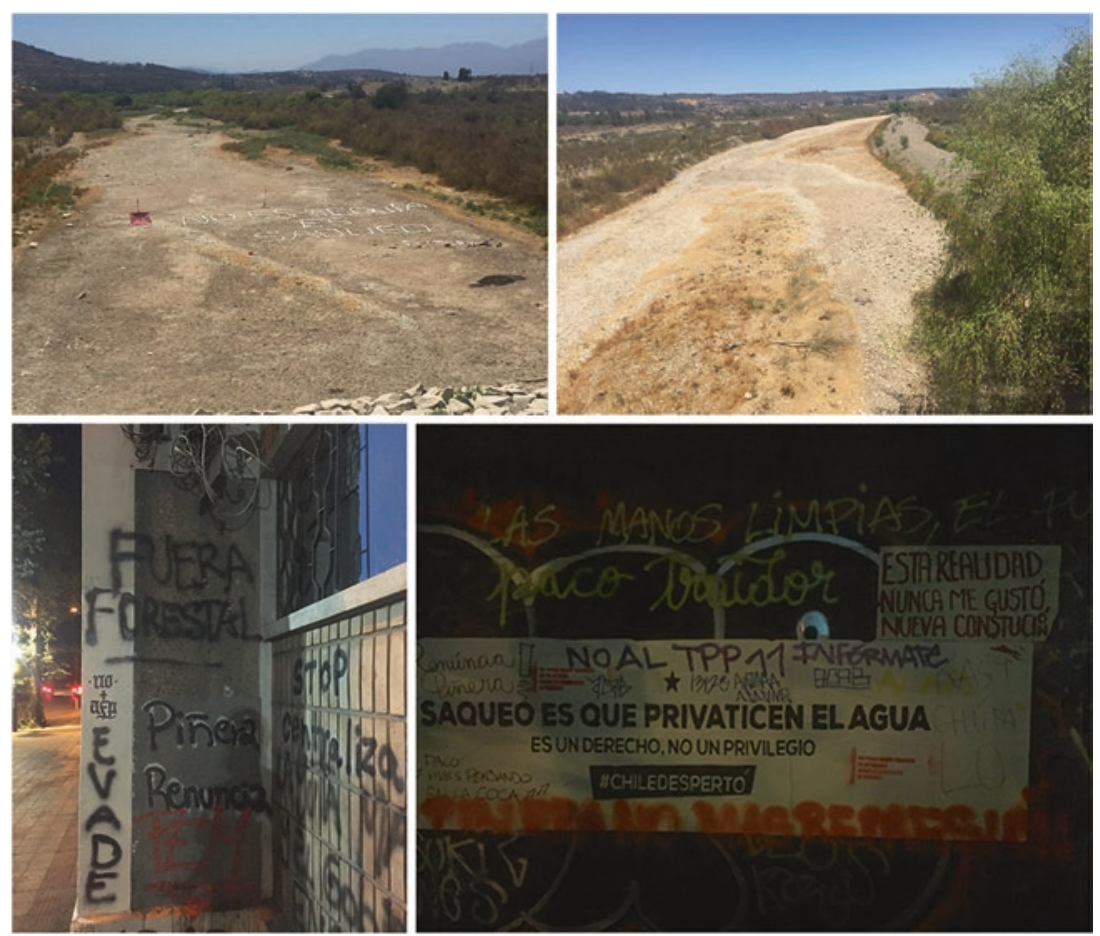

Fig. 1 Above, the Aconcagua River completely dried up in December 2019 and stones spelling out the message: "This is not a drought; this is water pillage." Below, political messages on the walls of Santiago in December 2019: on the left, a message against forestry corporations, and on the right, a message against water privatization and demanding the right to water. (Photos: Cristian Alarcón Ferrari) 
messages focused on water and environmental conflicts during the protests in 2019 and stone-made messages in a dry riverbed in the Valparaíso Region of central Chile.

In an attempt to deal with water scarcity, during the summer of 2020 the government launched a campaign to reduce water consumption which rested on private consumption decisions, particularly in Santiago, but without addressing the structural problems concerning water management and inequality in the current water crisis. Yet recently, a legal reform discussed in the parliament considered giving the national government the power to ensure and give priority to human consumption of water in cases of serious water stress and scarcity. On the other hand, the government launched a water roundtable to address the water crisis. Though they envisioned a roundtable with the limited participation of selected parties and the clear objective of keeping private property of water untouched, the new political context after the popular uprising in October 2019 forced the government to facilitate open discussions on the water crisis and strategies to face it. Thus, the water roundtable was open to public consultations and became a space for communicative struggles focused on the current legislation regulating the access to water resources (personal observation during an online seminar of the water roundtable in October 2020). This can also be seen in the results of the nationwide surveys organized by the government to assess opinions on water management, where $77.6 \%$ of respondents agreed that a basic principle in water legislation should be to "ensure continuous and sufficient access to water as a fundamental human right for personal and domestic use" (Mesa Nacional del Agua, 2020).

This needs to be understood in relation to the long struggle of local movements for water justice in Chile, and the resistance and alternatives articulated by these different territorial movements in the middle of the local social-ecological conflicts caused by the water crisis. The communication and material practice of these movements can be understood through the lens of claims to water justice, which raises important prospects for bottom-up meanings of water democracy. Water justice has been conceived as a basic demand for protection of water resources for human consumption and as a demand to ensure the sustainability of water resources at the local levels where water is extracted, but often for consumption in other places (Boelens et al., 2018). In turn, water democracy can be understood here as a situation where water users struggle and 
define strategies to participate in water decision-making and "do not passively bow to the top-down imposition of water policies and governance modes" (Hoogesteger, 2017). In what follows, I will show how environmental communication, power, and conflicts are constitutive aspects in the quest for water justice and water democracy in Chile.

First of all, there are three factors that are key to consider when analyzing and explaining how and why struggles for water justice and democracy have become so important in Chile recently. First, movements for water justice have constantly criticized the system of private property rights to water established through the privatization process under the Pinochet military dictatorship and maintained, and even deepened, during recent elected governments. Second, we have the social-ecological inequalities of the capitalist development of Chile's export-oriented economy, which is still based on exports originating in four economic activities that demand enormous quantities of water: mining, forestry and pulp production, fisheries, and agribusiness. Third, there is a megadrought that has lasted 10 years now and has aggravated water scarcity. In some areas this drought has coincided with the expansion of avocado plantations, which are now in places where extraction and accumulation of water make irrigation systems possible in dry areas (Duran-Llacer et al., 2020), and eucalyptus plantations, which are also associated with high water demand in dry areas (Alvarez-Garreton et al., 2019). Though eucalyptus plantations are not irrigated, their effects in some rural areas of southern Chile are similar to those of the avocado plantations in the north. In some other rural areas, the drought aggravates conflicts over water arising from projects to dam rivers for hydroelectrical and irrigation objectives. In what follows, I more deeply analyze such water conflicts by focusing on the three different regions, shown in Fig. 2, where I have carried out fieldwork and where the aforementioned factors interplay in water conflicts.

In the Santiago Metropolitan Region, where Chile's capital, Santiago, is located, about $70 \%$ of the drinking water is obtained from rural areas crossed by the Maipo River, approximately $35 \mathrm{~km}$ from downtown Santiago. Drinking water obtained from the Maipo River is commercialized by one large company, which needs to purify the water before delivering it to consumers in Santiago. This large private water company, Aguas Andinas, owned by the Spanish international water company Suez, was previously a publicly owned company, but its privatization began during the dictatorship, and it was then fully privatized in the post-dictatorship period. The company depends on water availability in the Maipo River and 
Fig. 2 Locations of fieldwork in the Valparaíso, Santiago, and Nuble regions of Chile. (This image used with permission of Blmbo, CC BY-SA 3.0 CL, via Wikimedia Commons)

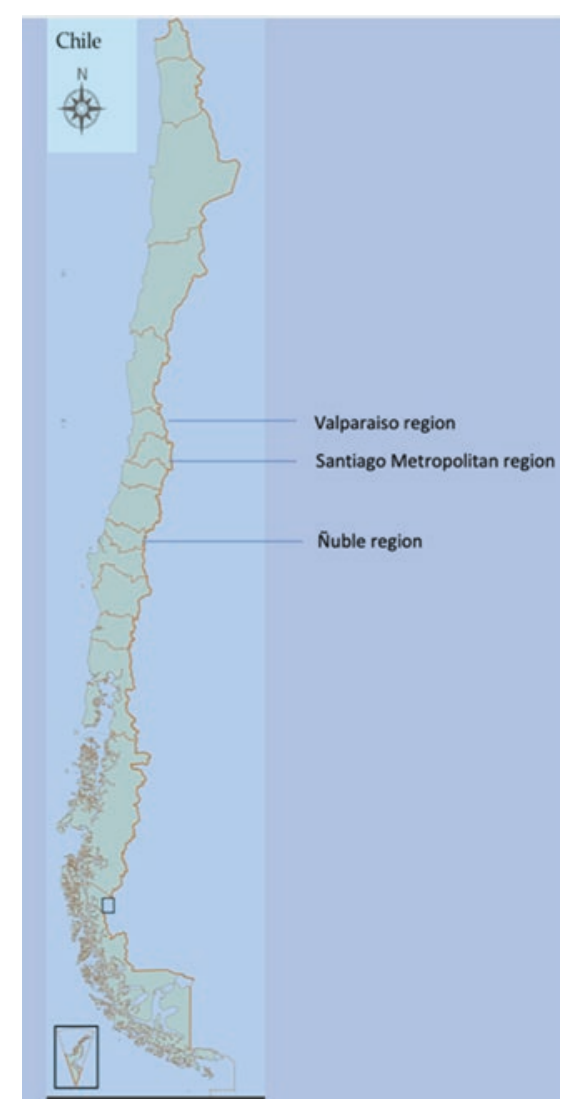

on the Yeso Dam in the Andes foothills. Due to the lack of snow and rain in 2019 , the dam had only $37 \%$ of its capacity in January 2020 , raising serious concerns about water availability in the future. In March 2020, rural areas in the Maipo Basin were declared to be in a state of water scarcity, and though in 2020 rains ameliorated the effects of the drought, this was not enough to end the drought. Due to water scarcity in the Maipo Valley, the water company is making investments to access more water sources and ensure water availability for Santiago, and its projects include well drillings in the suburbs of the city. In parallel with issues concerning water scarcity, the Maipo River is the site of a long conflict between local rural communities and national environmental groups that are opposing 
the Alto Maipo Hydroelectric Project. This project consists of damming and redirecting the Maipo River to produce and transfer electricity for consumption in other parts of the country, including mining industries in the north. A point of contestation here is the fact that the Alto Maipo Hydroelectric Project is based on a private commercial agreement between the water company and the Alto Maipo hydroelectric company. This private agreement ensures the hydroelectrical company the right to use water resources for which the water company has user rights. Thus, water use in these rural areas is mainly regulated as a private agreement between these two private companies. The threats to water resources implied by this project are not the only ones for the population of the city of Santiago. Recently, the same water company raised concerns about a mining project planned in another valley providing water to the city. Here, a main concern is that the Environmental Impact Assessment (EIA) for this mining project has not fully taken into account how it may affect water resources. Taking these two examples together shows that approaching the water crisis in Santiago requires an understating of the legislation contained in a water code that ensures private property rights to water resources. This water code is a product of the neoliberal project imposed in the country during the dictatorship, and reforms to change the property regime established in this water code proposed by several coalitions, including socialenvironmental movements, academics, and political movements, are resisted by business associations and politicians aligned with the interests of such businesses. Thus, water provision in Santiago is characterized by an institutional arrangement originating in the privatization of the main water company, the establishment of private property rights to water (which benefits the private water company, other economic organizations, and private owners), and the lack of public control on how to manage water resources. In this regard, Chilean water legislation is known as one of the most neoliberal water regulation policies in the world, as it ensures private property rights to water resources, and markets and private actors can act in the water markets with few public regulations (Bauer, 2015). In addition, privatization of water is deeply linked to inequal distribution of the now scarce water resources in the city of Santiago (Durán, 2015).

The water crisis in Chile has also dramatically materialized in the province of Petorca in the Valparaíso Region. While the drivers of the water crisis here are several, including less rain and snow in the Andes associated with the drought and climate change, the water conflicts are basically rooted in legal and illegal appropriation of water resources for 
agribusinesses in the context of water scarcity. In this regard, conflicts are associated with the aggressive expansion of avocado and citrus plantations for export, which dramatically reduces water availability for human consumption in the area. In this case, plantation owners use their private property rights to water to ensure irrigation and production, and in some cases, there has even been illegal appropriation of groundwaters to irrigate the plantations (Bolados García et al., 2018). As the pictures in Fig. 3 show, and as explained by informants during personal observations in the area, these avocado plantations are only possible because of the existence of water accumulators, which source water in dry areas where no plantations existed until recently. These accumulators obtain water through
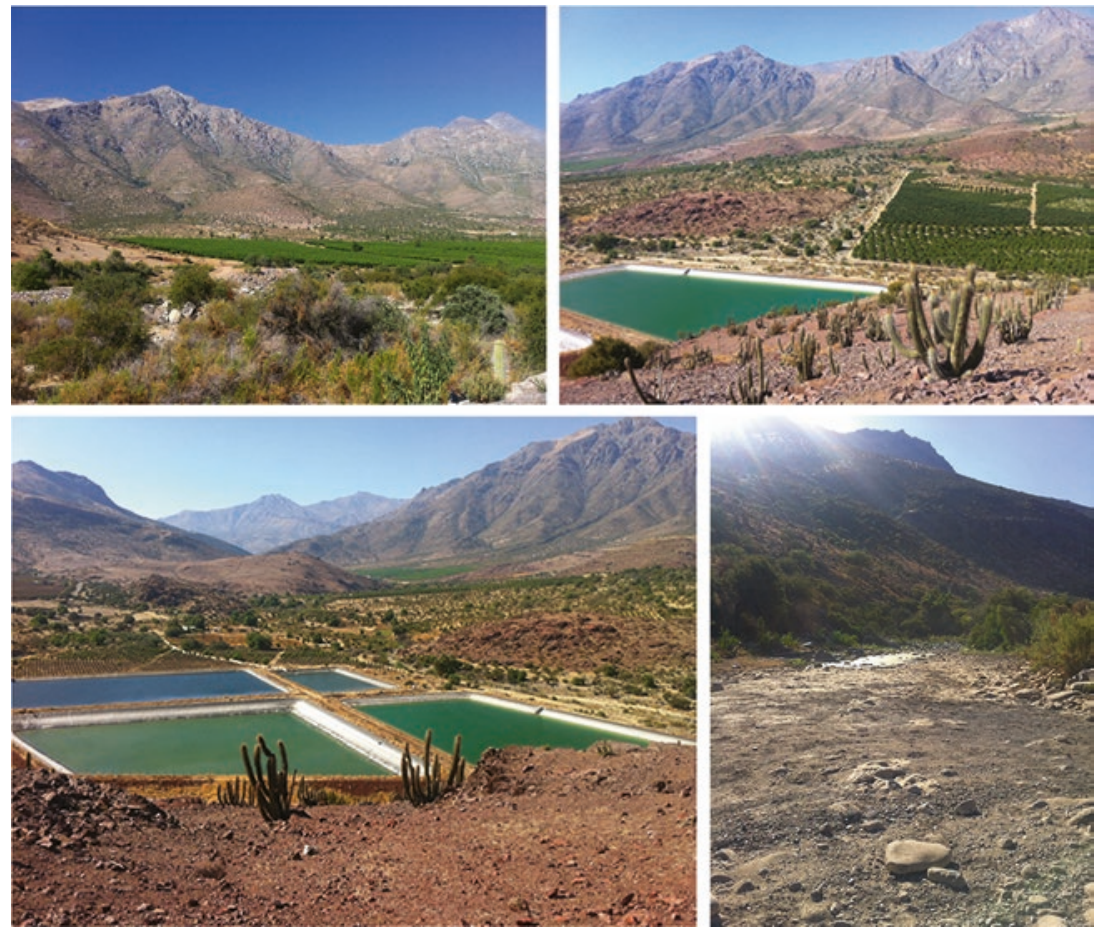

Fig. 3 Above, avocado plantations in the Andes foothills close to Petorca in the Valparaíso Region of Chile. Below, water accumulators for irrigation of avocado plantations and a dried-up stream close to the water accumulators. (Photo: Cristian Alarcón Ferrari) 
pipelines that connect different water extraction points in the Andes foothills and have been opposed by local movements and activists, who organize their demands around defending water resources for the local communities and ending the privatization of water and the system of private property rights to water resources. Crucially, they also demand support for alternative ways to access and use water resources, with a focus on human consumption as well as more sustainable food production systems.

Another region where the water crisis is especially noticeable is the Nuble Region in southern Chile, where industrial forestry plantations of exotic tree species such as eucalyptus and pines along with increasing irrigations needs for agribusinesses have led to local conflicts over water resources. In the case of industrial tree planting, increasing evidence of water scarcity due to fast-growing and water-intensive tree plantations have mobilized local actors to find ways to regulate and even stop tree planting. With regard to dam projects, local communities have opposed a major dam project which will also affect important native forest resources. Here, opposition during the EIA process did not succeed, and the company eventually obtained an environmental authorization to build the dam. Also, a hydroelectrical component project which was added to the project only recently obtained an environmental authorization through an EIA. Recently, hundreds of activists were able to stop the public auction for the right to use water from another major river and a watercourse in the region. These auctions are allowed in the Chilean legal system and, if successful, they entail exclusive rights to water. In these cases, demands for water use and water rights articulate political resistance to the privatization of water, but in some cases resistance also leads to land-use alternatives. This second form of resistance is represented by agroecological movements in the region, which have confronted the water crisis by elaborating and implementing agroecological systems that allow less water-intensive agriculture and the use of species that consume less water (Interviews and observations in the Nuble Region, December 2019).

When these water conflicts are taken together, the material and communicative articulation of popular movements defending water resources and demanding rights to water use reveal themselves to be a distinctive aspect of the struggles for water justice in Chile. Two characteristics of these movements can be considered in greater detail here. First, these are movements that communicatively question the legitimacy of the system of private property rights to water. Thus, at the center of this dispute are the political meanings of property rights to water resources and how they are 
contested. Second, these movements aim at giving a material meaning to demands for ensuring water use as a common good and the priority of human consumption of water. I would argue that this provides important grounds for empirically deepening a critical analysis of environmental communication in these water conflicts.

\section{A Critical Environmental Communication Analysis of Water Conflicts in Chile: Knowledge and Power over Water and Epistemologies of the South}

The struggles for water justice in Chile are not only multidimensional in the material sense but also multidimensional at the level of theory and epistemology. Thus, the analysis of environmental communication in this context needs to encompass the process of knowledge production and communicative struggles implied in giving meanings to rights and uses of water. In this sense, one can discern in the struggles for water justice in Chile that when local movements aim at protecting water resources for human consumption, they are at the same time struggling to create new meanings for water decision-making. Thus, in analyzing and explaining these struggles by deploying a critical conceptualization of environmental communication, the following prominent relations can be established. First, these water conflicts show how spaces of communicative struggles concerning water are brought about by the interests of different actors trying to produce and impose meanings on the problem and on the possible solutions to the conflicts. The struggle around private property rights to water shows this clearly. On the one hand, for those that ideologically and materially defend private property rights to water, this defense is part of their struggle to maintain the hegemony of the neoliberal project over water, and they use their power to defend private property rights and market mechanisms governing water resources by accommodating this defense to the context of sustainability concerns. In fact, one of the discourses reproduced in the water debate in Chile articulates the idea that property rights are part of the solution to the water crisis, and thus private water companies and agribusinesses have discursively engaged in active campaigns to show environmental credentials and alignment with sustainable development goals. In these intersections between environmental communication and power lie some of the main opposing forces articulating water conflicts in Chile. 
Second, as these cases also show, environmental communication is locally situated, conflict-oriented, and entangled in the wider conflictivity of neoliberal capitalism and the ideological and discursive articulation of hegemony in the environmental-policy-making process in Chile. On the other hand, the rise of movements for water justice in Chile shows how novel counterhegemonic forms of knowledge are today able to firmly articulate social power and so to materialize meanings and discourses of water justice in the country.

Third, these are struggles that refer constantly to the process of creating power to make water a common good, and they are articulated through the production of meaning about material access and control to water resources. This indicates that to critically theorize environmental communication in these specific contexts is an important step in understanding how and why power and environmental communication are inseparably linked within water conflicts in Chile. To theorize this, it is key to recognize the epistemological dimensions of the enactment of environmental communication by activists and organizations taking the side of the right to water and water justice in the struggles for water in Chile. In fact, a condition of possibility for these movements is the wide networks of communication and education and the processes of situated knowledge production which are communicatively expanded to form wider public spheres. As the process initiated by the water roundtable shows, the efforts to depoliticize the water discussion in Chile are impossible today because open channels of communication also mean freer ways to politicize the water discussion. Thus, demands for water democracy are the enactment of a political goal for water justice long in the making, and they enable us today to think about water justice in a much clearer political way. In a context like this, as de Sousa Santos suggests, we see the creative potential of the epistemologies of the South: If these struggles have so deeply resonated in the widespread rejection of neoliberalism that moved millions of Chileans to massively build the popular uprising of 2019 and then vote for a new constitution in 2020, it is because, to a crucial degree, another way of knowing the water crisis also enacted another way of conceiving social power over water. Thus, it is the social power of the people, their use of environmental communication versus corporate environmental communication, and the long struggles for water justice that today make the critique of property rights to water so pivotal in the political demonstrations against neoliberalism in Chile. And this is something that neither the government-led roundtable on water nor corporate environmental 
communication and their neoliberal-centric epistemology can accommodate or domesticate today.

\section{Concluding Remarks}

This chapter has offered some conceptual and theoretical insights to advance a conflict- and power-oriented perspective for a critical conceptualization of environmental communication. By drawing insights from Paulo Freire, Eric Wolf, the contemporary anthropology of power, and the epistemologies of the South, I have attempted to forge some conceptual links between environmental communication and anthropology. What emerges from this attempt, I argue, is one path to deepening our understanding of how and why environmental communication is ingrained in struggles over the meaning and materiality of social-ecological conflicts today. Furthermore, by establishing a clear link between this approach to environmental communication and the question of knowledge and power relations in the struggles for water justice in Chile, the chapter has brought into the discussion the role that environmental communication plays in shaping communicative and epistemological struggles. In this regard, the voices of people fighting for water justice in Chile show how environmental communication gets entangled with the everyday production of epistemologies of the South. In fact, water conflicts in Chile cannot be understood without approaching the overarching epistemological interests at stake in each local water conflict. In these contexts, as elsewhere, environmental communication is located at the center of such struggles and conflicts. To conclude, I would argue that this kind of critical theorizing of environmental communication is important today not only to better understand and explain the meanings of normative views of environmental communication but also to understand how such normative views cannot be separated from the interests of subjects situated in contingent social-ecological relations and conflicts.

Acknowledgments I am grateful for the very helpful comments, editorial support, and suggestions of Annelie Sjölander-Lindqvist and Michael Dove, and for the comments and suggestions from two anonymous reviewers. I would also like to thank the participants in the panel on Environmental Communication and Anthropology at the 2018 Applied Anthropology Conference in Philadelphia for their comments on the conference paper on which this chapter is based. This research was carried out during a postdoctoral fellowship at the Department of 
Development Sociology at Cornell University, supported by a postdoctoral scholarship granted by Chile's National Commission for Scientific and Technological Research-CONICYT (74170059), and during the author's affiliation with the Law School at the Universidad Academia de Humanismo Cristiano, Chile. Also, part of the empirical work was supported by a grant from FORMAS (the Swedish Research Council for Sustainable Development, grant number 2018-02341).

\section{REFERENCES}

Adams, R. N. (1975). Energy and structure: A theory of social power. University of Texas Press.

Alarcón, C. (2015). Forests at the limits. Forestry, land use and climate change from political ecology and environmental communication perspectives: The case of Chile o Sweden. Doctoral Thesis No. 2015: 5, Faculty of Natural Resources and Agricultural Sciences, Swedish University of Agricultural Sciences.

Alarcón, C. (2019). Transforming wood energy in Sweden and Chile: Climate change, environmental communication and a critical political ecology of international forestry companies. Critical Perspectives on International Business, 16, 361-377. https://doi.org/10.1108/cpoib-05-2018-0039

Alarcón, C. (2020). Crisis socioecológicas y educación popular ambiental en el mundo rural: la relevancia de Paulo Freire para los estudios críticos de la comunicación ambiental y la educación para el desarrollo sostenible. Paulo Freire. Revista de Pedagogía Critica, 24, 149-171.

Alvarez-Garreton, C., Lara, A., Boisier, J. P., \& Galleguillos, M. (2019). The impacts of native forests and forest plantations on water supply in Chile. Forests, 10, 473. https://doi.org/10.3390/f10060473

Bauer, C. J. (2015). Water conflicts and entrenched governance problems in Chile's market model. Water Alternatives, 8(2), 147-172.

Boelens, R., Vos, J., \& Perreault, T. (2018). Introduction: The multiple challenges and layers of water justice struggles. In R. Boelens, T. Perreault, \& J. Vos (Eds.), Water justice (pp. 1-32). Cambridge University Press.

Bolados García, P., Henríquez Olguín, F., Ceruti Mahn, C., \& Cuevas, A. S. (2018). La eco-geo-política del agua: Una propuesta desde los territorios en las luchas por la recuperación del agua en la provincia de Petorca (Zona central de Chile). Revista Rupturas, 8, 159-191.

Budds, J. (2013). Water, power, and the production of neoliberalism in Chile, 1973-2005. Environment and Planning D: Society and Space, 31, 301-318.

Castells, M. (2013). Communication power. Oxford University Press.

Cheater, A. (1999). Power in the postmodern era. In A. Cheater (Ed.), The anthropology of power (pp. 1-12). Routledge. 
Cox Callister, D. (2013). Land community participation: A new "public" participation model. Environmental Communication: A Journal of Nature and Culture, 7, 435-455.

Cox, R. (2010). Environmental communication and the public sphere. Sage.

de Sousa Santos, B. (2012). Public sphere and epistemologies of the South. Africa Development, 37, 43-67.

de Sousa Santos, B. (2015). Epistemologies of the South: Justice against epistemicide. Routledge.

de Sousa Santos, B. (2018). The end of the cognitive empire: The coming of age of epistemologies of the South. Duke University Press.

Durán, G. (2015). Agua y pobreza en Santiago de Chile: Morfología de la inequidad en la distribución del consumo domiciliario de agua potable. EURE (Santiago), 41, 225-246.

Duran-Llacer, I., Munizaga, J., Arumí, J. L., Ruybal, C., Aguayo, M., SáezCarrillo, K., Arriagada, L., \& Rojas, O. (2020). Lessons to be learned: Groundwater depletion in Chile's Ligua and Petorca watersheds through an interdisciplinary approach. Water, 12, 2446.

Escalona, J. L. (2016). Anthropology of power: Beyond state-centric politics. Anthropological Theory, 16, 249-262.

Franquesa, J. (2019). Resources: Nature, value and time. In J. G. Carrier (Ed.), $A$ research agenda for economic anthropology (pp. 74-89). Edward Elgar Publishing.

Freire, P. (1973). Extension or communication (L. Bigwood \& M. Marshall, Trans.). In Education for critical consciousness (pp. 91-164). Continuum International Publishing.

Freire, P. (2000). Pedagogy of the oppressed. Bloomsbury Publishing.

Gallie, W. B. (1955). Essentially contested concepts. Proceedings of the Aristotelian Society, 56, 167-198.

Habermas, J. (1973). Legitimation crisis. Beacon Press.

Hardt, H. (2008). Myths for the masses: An essay on mass communication. Wiley.

Hoogesteger, J. (2017). The politics of water democracy: Insights from grassroot struggles in the Ecuadorian Highlands. Asia Pacific Viewpoint, 58, 74-85.

Joas, H., \& Knöbl, W. (2009). Social theory: Twenty introductory lectures. Cambridge University Press.

Leff, E. (1994). Ecologia y capital: Racionalidad ambiental, democracia participativa y desarrollo sustentable. Siglo XXI.

Lukes, S. (2004). Power: A radical view. Red Globe Press.

Martin, R. (1971). The concept of power: A critical defence. The British Journal of Sociology, 22, 240-256.

McKenna, B. (2013). Paulo Freire's blunt challenge to anthropology: Create a pedagogy of the oppressed for your times. Critique of Anthropology, $33,447-475$. 
Mesa Nacional del Agua. (2020). Participación ciudadana. Primer informe consulta digital Mesa Nacional del Agua, Chile.

Milstein, T. (2009). Environmental communication theories. In S. W. Littlejohn \& K. A. Foss (Eds.), Encyclopedia of communication theory (pp. 345-349). Sage.

Norton, T. (2007). The structuration of public participation: Organizing environmental control. Environmental Communication, 1, 146-170.

Portis-Winner, I. (2006). Eric Wolf: A semiotic exploration of power. Sign Systems Studies, 34, 339-356.

Schwarze, S. (2007). Environmental communication as a discipline of crisis. Environmental Communication, 1, 87-98. https://doi.org/10.1080/ 17524030701334326

Senecah, S. L. (2004). The trinity of voice: The role of practical theory in planning and evaluating the effectiveness of environmental participatory processes. In S. P. Depoe, J. W. Delicath, \& M.-F. Aepli Elsenbeer (Eds.), Communication and public participation in environmental decision making (pp. 13-33). SUNY Press.

Wolf, E. R. (2001). Pathways of power: Building an anthropology of the modern world. University of California Press.

Open Access This chapter is licensed under the terms of the Creative Commons Attribution 4.0 International License (http://creativecommons.org/licenses/ by $/ 4.0 /$ ), which permits use, sharing, adaptation, distribution and reproduction in any medium or format, as long as you give appropriate credit to the original author(s) and the source, provide a link to the Creative Commons licence and indicate if changes were made.

The images or other third party material in this chapter are included in the chapter's Creative Commons licence, unless indicated otherwise in a credit line to the material. If material is not included in the chapter's Creative Commons licence and your intended use is not permitted by statutory regulation or exceeds the permitted use, you will need to obtain permission directly from the copyright holder.

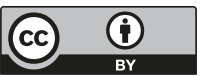

